\title{
Promoter melting and TFIID complexes on Drosophila genes in vivo
}

\author{
Charles Giardina, Mercè Pérez-Riba, ${ }^{1}$ and John T. Lis ${ }^{2}$ \\ Section of Biochemistry, Molecular and Cell Biology, Biotechnology Building, Cornell University, Ithaca, New York 14853 \\ USA
}

In vivo UV cross-linking and nuclear transcriptional run-on experiments have shown that a number of Drosophila genes possess an elongationally paused RNA polymerase on their 5' ends. Here, we examine in vivo promoters that do and do not possess paused polymerases using the single-stranded DNA-probing reagent $\mathrm{KMnO}_{4}$. Melted DNA helices are found associated with the pause site of the uninduced hsp 70 and $h s p 26$ heat shock genes and the constitutively expressed $\beta-1$ tubulin gene. The histone $H 1$ and $H 2 B$ genes, which lack a paused polymerase, have no comparable region of melted DNA. Melting at the pause site persists upon heat shock induction of the $h s p 70$ and $h s p 26$ genes, indicating that pausing continues after gene activation. Interestingly, activation triggers additional melting, both at the start site (in the region where open complexes would be expected to form) and downstream of the uninduced pause site. In the course of our studies, we discovered that some $\mathrm{T}$ residues of the TATA box were protected from $\mathrm{KMnO}_{4}$ modification in both induced and uninduced cells. This protection appears to be a consequence of TFIID binding, as a similar protection pattern could be produced in vitro with purified protein.

[Key Words: Transcriptional regulation; TATA-binding protein; RNA polymerase pausing; $\mathrm{KMnO}_{4}$; heat shock genes; Drosophila]

Received June 15, 1992; revised version accepted August 25, 1992.

The control of transcription at steps subsequent to the initiation of RNA synthesis is well documented in prokaryotes (Platt 1986; Spencer and Groudine 1990). Postinitiation control can be achieved through the modification of RNA polymerase (Roberts 1988; Nodwell and Greenblatt 1991) or RNA structure (Yanofsky 1987) to forms that either inhibit or enhance transcription termination. In addition, the progress of an elongating RNA polymerase can be impeded by the binding of a regulatory protein to DNA (Seelitti et al. 1987).

It is becoming increasingly apparent that transcriptional regulation at steps after initiation is also common in eukaryotes. One effect of the viral Tat protein in the regulation of human immunodeficiency virus-1 (HIV-1) mRNA synthesis is to increase the processivity of elongating RNA polymerase (Laspia et al. 1989; Marciniak et al. 1990). A number of mammalian cellular genes also display postinitiation regulation. For example, an elongational block has been found on the human and mouse c-myc gene (Bentley and Groudine 1986; Nepveu and Marcu 1986), and the human adenosine deaminase gene (Chinsky et al. 1989; Lattier et al. 1989).

Analyses of transcriptional complexes on certain Drosophila genes indicate that transcription can be con-

\footnotetext{
${ }^{1}$ Present address: Departament de Bioquimica i Fisiologia, Universitat de Barcelona, Barcelona, Spain.

${ }^{2}$ Corresponding author.
}

trolled at an early stage in RNA elongation. In vivo UV cross-linking of protein to DNA has revealed that an RNA polymerase is bound to the uninduced $h s p 70$ promoter (Gilmour and Lis 1986). Transcriptional run-on experiments with isolated nuclei revealed that this bound polymerase is transcriptionally engaged but paused after having transcribed $\sim 25$ bases (Rougvie and Lis 1988). Therefore, a step in early transcriptional elongation is rate limiting and would seem a likely target of regulation. The factors, or inherent properties of the transcription complex, that prevent the RNA polymerase from transcribing further into the $h s p 70$ gene can be inactivated (or dissociated) by Sarkosyl or high salt, thereby allowing the previously paused polymerase to elongate (Hawley and Roeder 1985; Rougvie and Lis 1988). A collection of Drosophila genes were surveyed using this Sarkosyl-stimulated run-on assay, and it was found that a number of heat-inducible and constitutively expressed genes support a transcriptionally engaged, but paused, RNA polymerase on their 5' ends (Rougvie and Lis 1990). For some of these genes, the high density of polymerase on the extreme $5^{\prime}$ end was confirmed by in vivo UV cross-linking of protein to DNA. It therefore appears that for a number of genes in Drosophila, the rate-limiting step in transcription occurs after RNA synthesis has begun.

Although UV cross-linking provides strong evidence for polymerase-DNA interactions at a promoter proxi- 
mal region of the gene, it could be argued that the transcriptional engagement of the polymerase observed in a transcriptional run-on assay is occurring during the isolation of nuclei. Furthermore, the transcriptional run-on technique gives a rather low resolution positioning of polymerase molecules. Here, we use the single-stranded DNA probing reagent $\mathrm{KMnO}_{4}$ to examine promoter melting in intact cells (Rubin and Schmid 1980). This reagent can map the melted DNA associated with open and transcribing polymerase complexes both in vitro and in vivo (Sasse-Dwight and Gralla 1988, 1989; Kainz and Roberts 1992; Wang et al. 1992). We find that genes previously reported to have a paused polymerase in nuclei (Rougvie and Lis 1988, 1990) also display a melted region of DNA immediately downstream of the transcriptional start site, when assayed in cells. This melted region of DNA presumably lies in the wake of the paused polymerase. Using $\mathrm{KMnO}_{4}$, we also monitor the changes in distribution of the polymerase on these genes upon activation. Gene activation results in DNA melting at the transcriptional start site, in a region where "open" polymerase complexes would be expected to form, as well as downstream of the pause site. Finally, we found rather unexpectedly an in vivo protection of the TATA box from the background reactivity of $\mathrm{KMnO}_{4}$ with doublestranded DNA. This protection could be reproduced in vitro using purified TATA-binding protein (TBP). $\mathrm{KMnO}_{4}$ can therefore detect both TBP and open or paused polymerase complexes in cells.

\section{Results}

\section{Melted DNA structures are detected in vivo at the $5^{\prime}$ end of the hsp 70 gene}

Because $\mathrm{KMnO}_{4}$ reacts with $\mathrm{T}$ (and, to a lesser extent, C) residues preferentially when they are in single-stranded DNA, we reasoned that this reagent would be useful for locating the transcription bubble resulting from the paused RNA polymerase on the $h s p 70$ gene. This reagent has been used previously to detect open and transcribing polymerase complexes both in vitro and in vivo (SasseDwight and Gralla 1988, 1989; Kainz and Roberts 1992; Wang et al. 1992). Bases modified by $\mathrm{KMnO}_{4}$ can be detected by direct primer extension to the modified base (Borowiec et al. 1987; Becker et al. 1989) or, after cleavage at the site of modification with piperidine, by the ligation-mediated polymerase chain reaction (LMPCR) technique (Mueller and Wold 1989; Pfeifer et al. 1989). This latter technique involves the ligation of a linker to the site of piperidine cleavage, thereby generating a substrate amenable to geometric amplification using PCR. Primers for the amplification include a linker primer together with genomic primers adjacent to the region of interest.

Figure 1A shows the sites of $\mathrm{KMnO}_{4}$ hyper-reactivity on the hsp70 gene in cells as detected by the LMPCR method. Under non-heat-shock conditions /the NHS lane), clear hyper-reactivity relative to purified DNA is observed from positions +22 through +40 on the coding

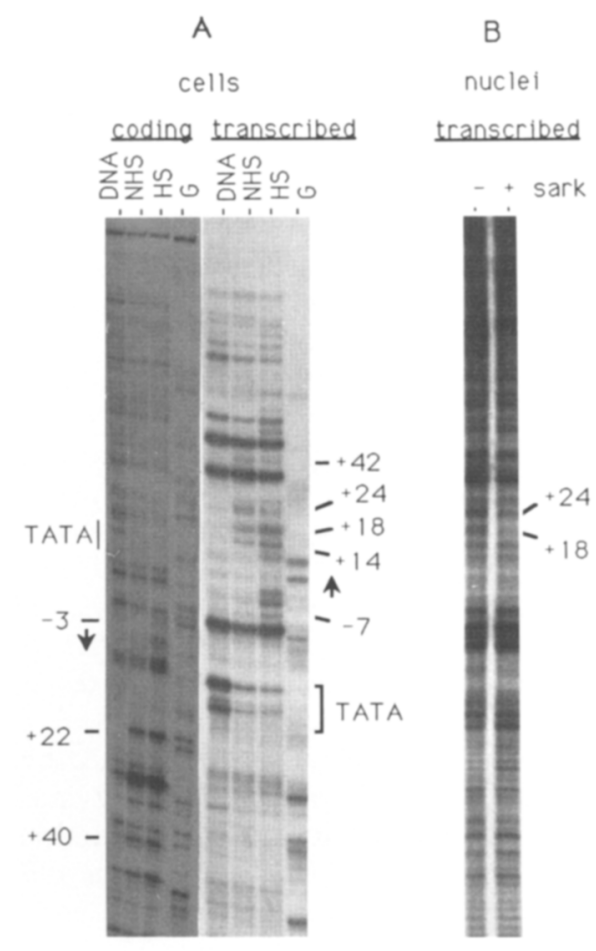

Figure 1. (A) $\mathrm{KMnO}_{4}$ hypersensitive site mapping on the coding and transcribed strands of the hsp 70 gene in Drosophila cells (Kc). Non-heat-shocked cells (NHS), heat-shocked cells (HS), and purified genomic DNA (DNA) were treated with $25 \mathrm{~mm}$ $\mathrm{KMnO}_{4}$ for $30 \mathrm{sec}$ at $0^{\circ} \mathrm{C}$. All DNAs were then purified, cut with restriction enzyme, and treated with piperidine to cleave at the $\mathrm{KMnO}_{4}$ modification sites. The DNA was amplified and radiolabeled using the LMPCR technique to display either the coding or transcribed strand of the $h s p 7087 \mathrm{~A}$ genes (as indicated). G ladders were prepared using DMS followed by piperidine cleavage and LMPCR. The XbaI cleavage site on the coding strand is found at the top of the gel; the ClaI cleavage site on the transcribed strand is not shown. The arrows indicate the position of the transcriptional start site. $(B)$ Reduction of $\mathrm{KMnO}_{4}$ reactivity in the pause site under conditions where paused polymerase can be induced to transcribe into the body of the hsp 70 gene. Nuclei from Drosophila SL2 cells were treated with $25 \mathrm{mM} \mathrm{KMnO}_{4}$ for $15 \mathrm{sec}$ under transcriptional run-on conditions either in the presence or absence of $0.6 \%$ Sarkosyl, as indicated. $\mathrm{KMnO}_{4}$ modification sites on the transcribed strand were displayed using the direct primer extension technique.

strand and from +14 through +42 on the transcribed strand (for compiled results, see Fig. 5, below). Such a pattern of hyper-reactivity would be predicted for an RNA polymerase paused at a step early in the transcription of the $h s p 70$ gene. The position of this hyper-reactivity was anticipated as the paused RNA polymerase on the $h s p 70$ gene was estimated to be, on average, at approximately position +25 (Rougvie and Lis 1988). The size of the melted region is larger than that expected for an RNA polymerase paused at a single site and, instead, is more consistent with the existence of multiple (clustered) pause sites (see Discussion).

The paused polymerase can be induced to transcribe 
into the body of the gene by the addition of Sarkosyl (Rougvie and Lis 1988). We reasoned that such treatment should reduce the reactivity of $T$ residues at the site of the paused polymerase. Figure $1 \mathrm{~B}$ shows the reactivity pattern on the transcribed strand of the $h s p 70$ gene in nuclei treated with or without Sarkosyl as detected by the direct primer extension technique. The signals at sites +18 through +25 on the transcribed strand /which were found to be hyper-reactive in Fig. 1A) are decreased upon treatment with Sarkosyl. This result therefore provides additional evidence that the $\mathrm{KMnO}_{4}$ hyper-reactivity in this region is the result of DNA melting caused by a paused polymerase. It should also be noted that genes not found to support a paused polymerase in the transcriptional run-on assay likewise do not display melted DNA structures at their $5^{\prime}$ ends (see below). The melted DNA positions +14 through +42 on the $h s p 70$ gene are therefore most easily interpreted as being the result of a paused RNA polymerase in this region.

Transcriptional run-on studies performed by $\mathrm{O}^{\prime} \mathrm{Brien}$ and Lis indicated that polymerase pausing on the $h s p 70$ gene persists at intermediate levels of induction (at temperatures of $27^{\circ} \mathrm{C}$ and $30^{\circ} \mathrm{C}$; $\mathrm{O}^{\prime}$ Brien and Lis 1991). However, at higher levels of induction $\left(33^{\circ} \mathrm{C}\right.$ and $\left.37^{\circ} \mathrm{C}\right)$, it became impossible to detect the contribution of a single, paused, Sarkosyl-stimulated polymerase on the $5^{\prime}$ end of the gene owing to the high levels of RNA being produced by actively transcribing polymerases. Likewise, the resolution of earlier UV cross-linking studies was not sufficient to address this issue. The high resolution afforded by the $\mathrm{KMnO}_{4}$ assay allows the detection of a paused polymerase on the highly induced gene. Figure 1A shows the $\mathrm{KMnO}_{4}$ reactivity of both the transcribed and coding strands of the hsp 70 gene after induction at $37^{\circ} \mathrm{C} /$ the HS lanes). Upon full induction, the hyper-reactive sites on the DNA in the region of the paused polymerase persist at approximately the same intensity. Quantitative gel scanning of three separate experiments support this assessment. We interpret the persistence of $\mathrm{KMnO}_{4}$ hyperreactivity to be the result of a high concentration of transcriptionally paused RNA polymerase molecules on the $5^{\prime}$ end of the gene. This finding is therefore in agreement with the model in which the polymerase passes through a slow step (pauses) early in elongation, even when the gene is being highly transcribed (O'Brien and Lis 1991).

Heat shock induction also results in the generation of hyper-reactive sites both upstream and downstream of the non-heat-shock polymerase pause site. Upstream of the pause site, hyper-reactivity is detected from -7 through +12 . The open polymerase complex formed by the Escherichia coli RNA polymerase melts a region of DNA from approximately -12 through +3 /von Hippel et al. 1984; Kainz and Roberts 1992). We propose that the $\mathrm{KMnO}_{4}$ hyper-reactivity within the -12 through +3 region of the $h s p 70$ gene is the result of an open polymerase complex. If this is so, open complexes accumulate on the $h s p 70$ gene after induction. Heat shock-induced hyper-reactive sites are also detected at sites further into the body of the gene. Hyper-reactivity fades as one proceeds into the gene (weak hyper-reactivity can be de- tected up to about +90 ). This broad range of hyper-reactivity suggests that after induction, polymerase moves slowly through a large portion of the 5 ' region, encompassing the non-heat-shock pause site. However, the lack of substantial hyper-reactivity beyond this region indicates that there are no additional, discretely positioned, paused polymerase molecules on the region of hsp70 examined (up to a ClaI site at +264 ).

\section{In vivo occupancy of the TATA box in whole cells as assessed with $\mathrm{KMnO}_{4}$}

Another noticeable feature in the $\mathrm{KMnO}_{4}$ pattern of DNA in cells is the reduced reactivity of $\mathrm{T}$ residues of the hsp 70 gene in the TATA box (Fig. 1A). This protection is found on both the coding and transcribed strands of $h s p 70$ (Fig. 2A). A similar region of protection is also found on the hsp26 gene (Fig. 3). Surprisingly, TATA protection is less pronounced on the $\beta-1$ tubulin and histone $H 2 B$ genes (Fig. 4; the histone $H 1$ gene, also shown in Fig. 4, has no TATA box). We reasoned that this protection is most likely the result of the binding of the TBP component of TFIID to the TATA box (Parker and Topol 1984; Wu 1984; Hoey et al. 1990; Muhich et al. 1990). The protection of these T residues is the same in heat-shocked and non-heat-shocked cells, a finding consistent with earlier chromatin footprinting experiments performed in isolated nuclei where a constitutive protection of the TATA region from exonuclease III and

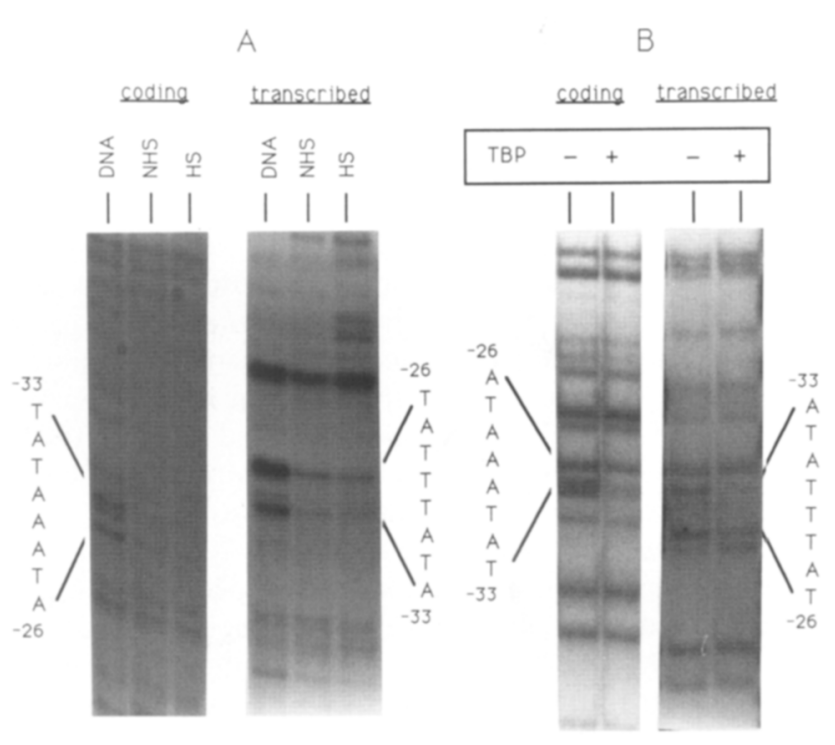

Figure 2. (A) Protection of the $h s p 70$ TATA box from $\mathrm{KMnO}_{4}$ in Drosophila cells. Samples were prepared as in Fig. 1A, with gel loadings adjusted to give a balanced presentation of the TATA region. $(B)$ In vitro protection of the $h s p 70$ TATA box from $\mathrm{KMnO}_{4}$ modification by purified TBP. A DNA fragment from the $h s p 70$ gene, singularly end-labeled on either the transcribed or coding strand, was incubated with purified human TBP as indicated. These binding reactions were treated with 25 $\mathrm{mM} \mathrm{KMnO}_{4}$ for $30 \mathrm{sec}$ at room temperature. $\mathrm{KMnO}_{4}$ modification sites were determined by cleavage with piperidine. 


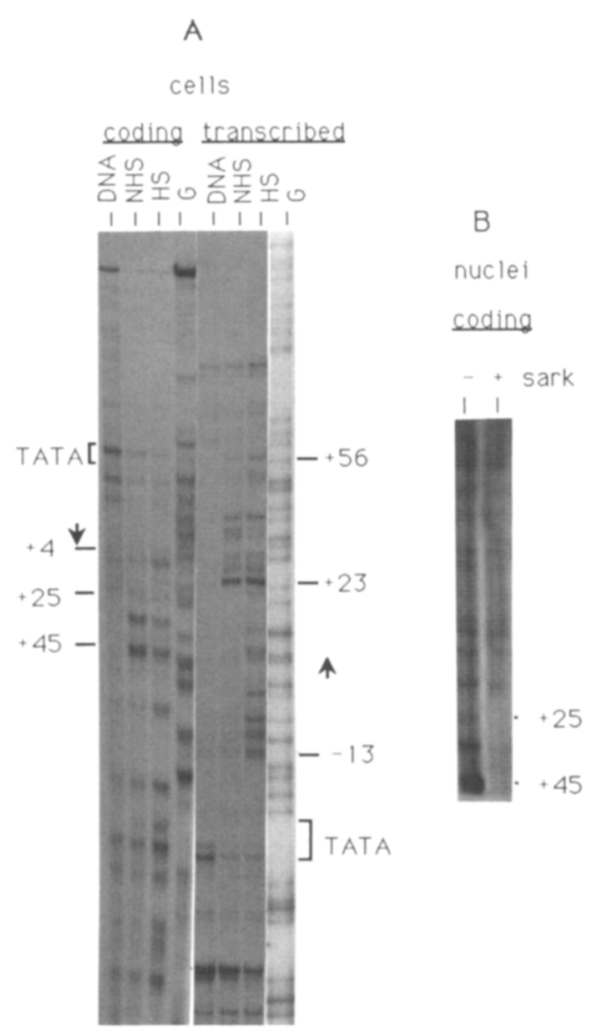

Figure 3. (A) $\mathrm{KMnO}_{4}$ hypersensitive site mapping on the coding and transcribed strands of the hsp26 gene in cells (Kc). Nonheat-shocked cells (NHS), heat-shocked cells (HS), and purified genomic DNA (DNA) were treated with $\mathrm{KMnO}_{4}$ and processed as described in Fig. 1A. LMPCR was used to detect $\mathrm{KMnO}_{4}$ modification sites on the coding and transcribed strands of hsp26. The DraI cleavage site on the coding strand is found at the top of the gel; the BanII cleavage site on the transcribed strand is not shown. The arrows indicate the position of the transcriptional start site. $(B)$ Under conditions where paused polymerase can be induced to transcribe into the body of the hsp26 gene, $\mathrm{KMnO}_{4}$ hyper-reactivity at the pause site is reduced. Nuclei from SL2 cells were treated as described in Fig. 1B. $\mathrm{KMnO}_{4}$ modification sites on the coding strand were displayed using the direct primer extension technique.

DNase I digestion has been observed (Wu 1984; Thomas and Elgin 1988).

Because TBP is most likely responsible for the observed protection of the TATA box, purified human TBP was tested for its ability to protect the TATA box from $\mathrm{KMnO}_{4}$ modification in vitro. As shown in Figure 2B, T residues of the TATA box are protected by TBP from reacting with $\mathrm{KMnO}_{4}$. Human TBP was used in this experiment for reasons of availability, but owing to the high conservation of the TBP DNA-binding domain, it is expected that the Drosophila TBP would give a similar pattern of protection (Hoey et al. 1990; Muhich et al. 1990; Greenblatt 1991). Proteins that are bound to DNA do not generally protect underlying DNA sequences from $\mathrm{KMnO}_{4}$ modification (Borowiec et al. 1987; C. Giardina and J. Lis, unpubl.). Possible explanations for why
TBP protects the TATA box from reacting with $\mathrm{KMnO}_{4}$ are presented in the Discussion.

\section{Melted DNA structures are detected in vivo at the $5^{\prime}$ end of the hsp26 gene}

Another heat shock gene that is found to support a paused polymerase is the $h s p 26$ gene (Rougvie and Lis 1990). The $\mathrm{KMnO}_{4}$ hyper-reactivity of the hsp26 gene was mapped to compare its hyper-reactivity with that found on the $h s p 70$ gene. Figure $3 \mathrm{~A}$ shows the $\mathrm{KMnO}_{4}$ reactivity on the uninduced hsp26 gene in cells as detected by the LMPCR method and by direct primer extension. Results obtained using the LMPCR technique show hyper-reactivity on the coding strand from +25 through +45 and on the transcribed strand from +23 through +56 (for compiled results, see Fig. 5). The hyperreactive sites on the coding strand of the hsp26 gene in nuclei can be cleared by Sarkosyl, as would be expected

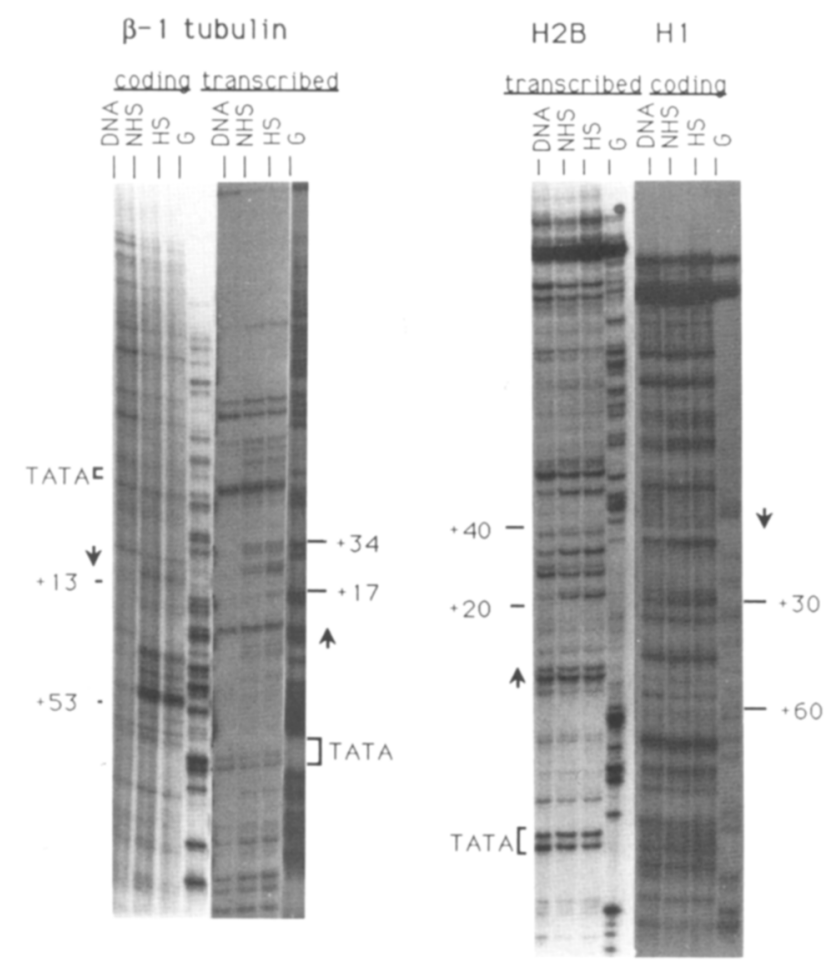

Figure 4. $\mathrm{KMnO}_{4}$ hypersensitive site mapping on the coding and transcribed strands of the $\beta-1$ tubulin gene, the transcribed strand of the histone $H 2 B$ gene, and the coding strand of the histone $H 1$ gene, in cells (Kc). Non-heat-shocked cells (NHS), heat-shocked cells (HS), and purified genomic DNA (DNA) were treated with $\mathrm{KMnO}_{4}$ and processed as described in Fig. 1A. Modification sites were detected as in Fig. 1A, probing to display the indicated strands. The DraI cleavage site (and a partial digestion product) on the coding strand of the histone $H 1$ gene, and the Avall cleavage sites on the transcribed strands of the $\beta-1$ tubulin and histone $H 2 B$ genes can be seen at the top of the respective gels. The AvaII cleavage on the coding strand of the $\beta-1$ tubulin gene is too distant to be detected. The arrows indicate the transcriptional start site positions. 
Figure 5. $\mathrm{KMnO}_{4}$ hyper-reactive $\mathrm{T}$ residues on the $h s p 70$, hsp26, and $\beta-1$ tubulin genes under heat-shock and non-heatshock conditions. Results from Figs. 1, 3, and 4 are summarized with $\mathrm{KMnO}_{4}$ hyperreactive residues indicated by arrows. Results obtained using heat-shocked cells are displayed closest to the DNA with results using non-heat-shocked cells presented on the next tier. The underlined sequences may have a role in generating a paused polymerase, as discussed in the text.

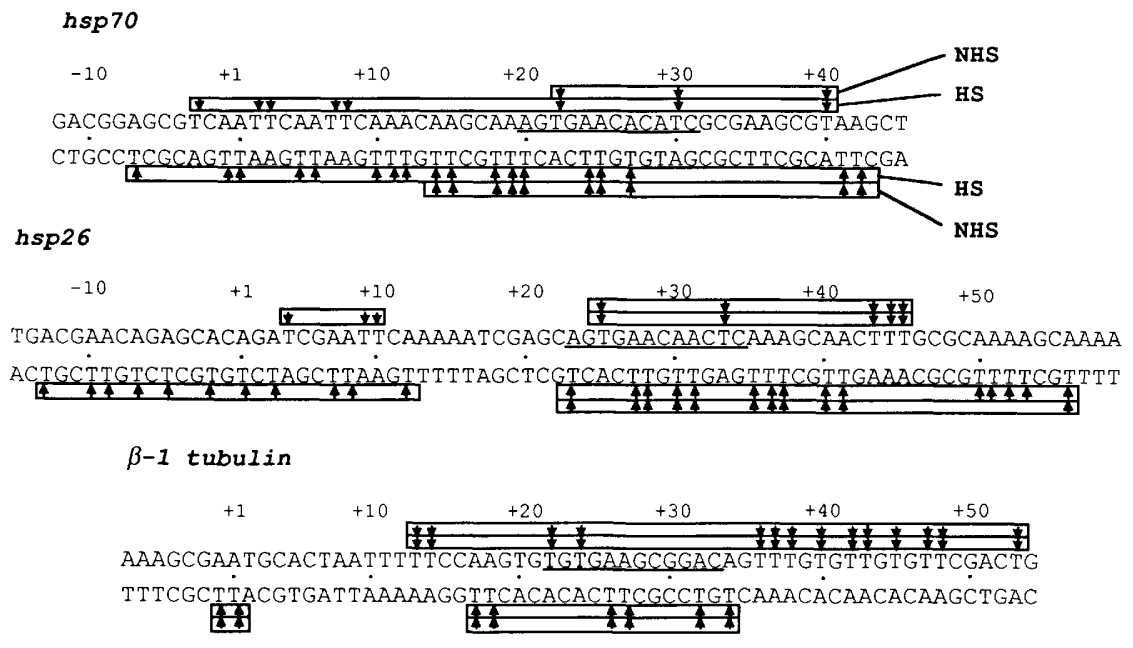

if the melted DNA was the result of a paused polymerase (Fig. 3B, with sites displayed by direct primer extension in this case). From these data (and for the reasons presented above), we conclude that polymerase pauses on the hsp26 gene in the region of +23 through +56 . The region of pausing on the $h s p 26$ gene is centered $\sim 12 \mathrm{bp}$ downstream of that found on the $h s p 70$ gene and is similar in size, that is, $\sim 30 \mathrm{bp}$.

Upon heat induction, the degree of DNA melting on the hsp26 gene in the region of the start site (from sites -13 through +17 ) is increased, with additional sites also appearing downstream of +56 . The changes in $\mathrm{KMnO}_{4}$ hyper-reactivity found on the $h s p 26$ gene upon induction are therefore similar to the changes found on the $h s p 70$ gene upon induction, with sites both upstream and downstream of the non-heat-shock pause site increasing in reactivity. The persistence of $\mathrm{KMnO}_{4}$ reactivity throughout the $5^{\prime}$ region of the $h s p 26$ gene after induction is taken as evidence of a high concentration of polymerase molecules in this region and indicates that elongational pausing continues to occur after induction, as proposed for the $h s p 70$ gene. Again, we interpret DNA melting at positions encompassing the start site as being the result of an open polymerase complex (von Hippel et al. 1984). It should be noted that a region of DNA between the pause site and the putative open complex is not hyper-reactive with $\mathrm{KMnO}_{4}$, suggesting that a contiguous bubble from the start site through the pause site is not formed after activation.

\section{Melted DNA structures are present at the $5^{\prime}$ end of a constitutively expressed gene}

The transcriptional run-on assay has demonstrated that Drosophila genes vary in their ability to support a paused polymerase (Rougvie and Lis 1990). The $\beta$-1 tubulin gene is found to support a paused polymerase whereas the histone $H 1$ and $H 2 B$ genes do not. To determine whether $\mathrm{KMnO}_{4}$ probing of cells corroborates the transcriptional run-on data, the $\mathrm{KMnO}_{4}$ hyper-reactivity of the $\beta-1 \mathrm{tu}$ bulin, histone $H 1$, and histone $H 2 B$ genes was analyzed.
Additionally, we wished to determine whether the changes in $\mathrm{KMnO}_{4}$ reactivity observed on the heat shock genes upon induction were specific for these genes or whether this phenomenon was a general effect of heat that could be observed on all genes.

On the $\beta-1$ tubulin gene, one set of $\mathrm{KMnO}_{4}$ hyperreactive sites (as displayed by the LMPCR method) is found on the transcribed strand stretching from +17 through +34 and on the coding strand from +13 through +53 (Figs. 4 and 5). This finding is therefore consistent with the transcriptional run-on data. Moreover, transcriptional run-on reactions performed with RNA chain terminators have estimated the polymerase pause site on the $\beta-1$ tubulin gene to be somewhere between +33 and +47 (Rougvie 1989). The $\mathrm{KMnO}_{4}$ probing and transcriptional run-on results together make a strong case for polymerase pausing in this region. Also, DNA melting is detected at the -1 and +1 positions on the $\beta$-1 tubulin gene, which is consistent with the presence of a polymerase open complex (von Hippel et al. 1984). As a similar complex is also found on the heat shock genes only after activation, the coexistence of the paused polymerase with this complex appears to correlate with an active transcriptional state. The intensities of the -1 and +1 sites do not change upon heat shock. This result indicates that the increased start site melting on the heat shock genes is not a general effect of heat but, instead, appears to be related to their increased rate of transcription.

On the histone $H 1$ and $H 2 B$ genes, where a paused polymerase has not been detected by the transcriptional run-on technique (Rougvie and Lis 1990), no region of $\mathrm{KMnO}_{4}$ hyper-reactivity comparable to that found on hsp70, hsp26, and $\beta$-1 tubulin is detected (Fig. 4). Close inspection does show a region of slight hyper-reactivity on the histone $\mathrm{Hl}$ gene at about +30 and on the histone $H 2 B$ gene at about +20 . These hyper-reactive sites could be the result of low level polymerase pausing not detected by the nuclear run-on assay. In general, however, these results support the hypothesis that the $\mathrm{KMnO}_{4}$ hyper-reactivity found on $h s p 70, h s p 26$, and $\beta-1$ tubulin 
genes is the result of the elongationally paused polymerase detected in nuclei.

The histone genes analyzed here also lack detectable $\mathrm{KMnO}_{4}$ hyper-reactivity over the start site. This result could mean that the persistence of the start site complex is longer on genes where polymerase pausing is found. Alternatively, the degree of start site melting could be dictated by promoter properties unrelated to the pausing phenomenon.

\section{Discussion}

Detection of the paused polymerase transcription bubble in vivo

Transcription of a eukaryotic gene could potentially be regulated at any of the many steps required to generate a complete RNA. These steps include the modulation of promoter accessibility, preinitiation complex formation, initiation, the transition from initiation to early elongation, and elongation through pause and termination sites. These steps can be divided further, as has been demonstrated by the elegant dissection of preinitiation complex assembly (Van Dyke et al. 1988; Buratowski et al. 1989|. One approach to identifying rate-limiting and potentially regulated steps in transcription is to gauge the progress of RNA polymerase through these steps in vivo. Our past studies have shown that an RNA polymerase complex is present on the $5^{\prime}$ end of the uninduced $h s p 70$ gene in vivo and that a polymerase is transcriptionally engaged but paused at this location in isolated nuclei (Gilmour and Lis 1986; Rougvie and Lis 1988). These studies imply that the polymerase has ready access to this uninduced gene and can initiate transcription but is impeded in its ability to progress beyond this early elongation mode. Similar observations have been made on other heat shock genes and on some constitutively expressed genes (Rougvie and Lis 1990).

In this study we probe at high resolution in vivo both heat-inducible and constitutively expressed genes for transcription bubbles generated by a paused RNA polymerase. This melted DNA is detected with $\mathrm{KMnO}_{4}$, a reagent that preferentially reacts with pyrimidines in single-stranded DNA. This reagent has been used previously to map the melted DNA associated with open and transcribing polymerase complexes both in vitro and in vivo (Sasse-Dwight and Gralla 1988, 1989; Kainz and Roberts 1992; Wang et al. 1992). This present study, however, and one by Krumm et al. (this volume) provide the first view of these complexes in a eukaryotic cell. We detect regions of hyper-reactivity to $\mathrm{KMnO}_{4}$ (as compared with naked DNA) on the 5' ends of genes that have been found to support a paused RNA polymerase in the transcriptional run-on assay ( $h s p 70, h s p 26$, and $\beta-1$ tubulin) but not on ones that do not show such support (histone H1 and H2B) (Rougvie and Lis 1990). The fact that substantial $\mathrm{KMnO}_{4}$ hyper-reactivity is observed only on genes found to support a paused polymerase provides evidence that the DNA melting detected by $\mathrm{KMnO}_{4}$ is most probably the result of an elongationally paused polymerase molecule. Other lines of evidence also support this contention. The region of helix melting on the $h s p 70$ gene correlates with the position of the paused polymerase estimated previously by analyzing RNA produced in transcriptional run-on experiments, that is, at approximately position +25 (Rougvie and Lis 1988). Also, the melted region of DNA found on the $h s p 70$ and $h s p 26$ genes in isolated nuclei can be cleared under transcriptional run-on conditions by the addition of Sarkosyl. Such a result would be predicted, because the paused polymerase in isolated nuclei can be induced to elongate into the body of the gene through the addition of Sarkosyl (Rougvie and Lis 1990). The melted region of DNA detected by $\mathrm{KMnO}_{4}$ is therefore most easily interpreted as being the result of a paused polymerase molecule.

Size, location, and sequence of the paused polymerase transcription bubble

Compared with $h s p 70$, the region of polymerase pausing on the $h s p 26$ and $\beta-1$ tubulin genes is centered $\sim 12$ and $5 \mathrm{bp}$ farther into the gene, respectively (Fig. 5). The size of the melted region is found to vary slightly in size$\sim 29$ bp on the $h s p 70$ gene, 34 on hsp26, and 40 on $\beta-1$ tubulin. The transcription bubble for the $E$. coli RNA polymerase spans $\sim 17$ bp (von Hippel et al. 1984; Kainz and Roberts 1992). Although it has not been established that the transcription bubbles of RNA polymerase II and the E. coli RNA polymerase are identical, the structural similarity between the two enzymes argue that they should be similar (Allison et al. 1985; Darst et al. 1991). It would therefore appear that either the paused polymerase transcription bubble is nonstandard or polymerase pausing occurs at multiple sites on the $5^{\prime}$ ends of these genes. High resolution mapping of the polymerase pause site using RNA chain terminators in a transcriptional run-on reaction agrees with a multiple pause site model (E. Rasmussen and J. Lis, unpubl.). These data reveal a number of pause sites that coincide with the bubble detected in the experiments presented here. We therefore currently favor a model in which polymerase pauses at multiple sites on the $5^{\prime}$ ends of a gene.

Depending on how the paused polymerase molecules are arranged on the $h s p 70$ and $h s p 26$ genes and on the length of the RNA : DNA duplex in the elongation complex, one might expect to find non-hyper-reactive $T$ residues on the transcribed strand within the transcription bubble as a result of the RNA : DNA duplex. A number of such $\mathrm{T}$ residues are found on both the $h s p 70$ and $h s p 26$ genes $(+29$, +35 , and +36 on $h s p 70$, and +50 through +53 on hsp26). Although the non-hyper-reactivity of these residues could be explained by RNA : DNA base pairing, other possibilities exist, such as an intimate association with protein factors or polymerase.

Mutational analysis of the $h s p 70$ promoter has indicated that sequences in the region of the pause site contribute to both paused polymerase formation and overall gene expression (Lee et al. 1992). Although it is not sufficient by itself, the region between +23 and +30 of the 
hsp70 gene is found to play some role in generating a paused polymerase. One might therefore expect to find a similar sequence element in the pause sites of the $h s p 26$ and $\beta-1$ tubulin genes. A sequence element extending from +20 through +31 on the $h s p 70$ gene is found to have a 10 out of 12 match to the +23 through +34 stretch on the hsp26 gene /underlined sequences in Fig. 5). In both cases, this element is positioned completely inside the paused polymerase transcription bubble. A 12bp stretch of DNA within the paused polymerase transcription bubble on the $\beta$ - 1 tubulin gene shares some homology with this sequence element, albeit a less extensive one. The +22 through +33 stretch of DNA on the $\beta-1$ tubulin gene has a 6 out of 12 match, with the consensus sequence derived from the two heat shock genes. Although provocative, the determination of the functional significance of this sequence element awaits point mutational analysis in transgenic flies.

\section{Polymerase pausing persists after induction}

$\mathrm{KMnO}_{4}$ probing has revealed that polymerase pausing persists on the $h s p 26$ and $h s p 70$ heat shock genes even after induction. This result indicates that pausing is not simply a negative regulatory event but, instead, may be an integral step in the transcription of these genes. The analysis of mutant $h s p 70$ constructs supports this contention; genes with a compromised ability to generate a paused polymerase likewise have a lower level of induced transcription (Lee et al. 1992). Heat induction results in an $\sim 100$-fold increase in the transcription of the heat shock genes (Gilmour and Lis 1985) and, therefore, must result in an equivalent increase in the rate at which the polymerase escapes from its paused state and transcribes into the gene. Given that there is no decrease in the number of polymerase molecules at the pause site after induction, the rate at which paused polymerase is loaded into the pause site must increase to match the increased rate at which it is released into the gene. The detection of what may be open polymerase complexes on the induced heat shock genes could be indicative of an increase in the rate of initiation. The precise coupling between paused polymerase loading and firing suggests that the two processes are mechanistically linked. One possibility is that the paused polymerase limits the rate of transcriptional initiation and the acceleration of paused polymerase release results in an equivalent increase in the rate of initiation. Conversely, paused polymerase release might be limited by the rate of polymerase initiation. In this latter model, one could envision paused polymerase being restrained by contacts with the initiation apparatus, with these contacts being broken by the initiation of the next polymerase.

$\mathrm{KMnO}_{4}$ footprinting indicates in vivo occupancy of the TATA region by TFIID

We found that the TBP component of TFIID protects $T$ residues of the TATA box from $\mathrm{KMnO}_{4}$ modification in vitro. This pattern of protection is similar to that ob- served over the TATA box in cells. This result was surprising because DNA-binding proteins are not usually found to protect DNA from $\mathrm{KMnO}_{4}$ modification (Borowiec et al. 1987). $\mathrm{KMnO}_{4}$ is believed to modify the DNA by attacking the C5-C6 double bond of pyrimidines, a moiety found in the major groove. It is possible that TBP protects the TATA box by simply shielding the C5-C6 bond from the solvent. However, because TBP interacts with DNA through the minor groove (Lee et al. 1991; Starr and Hawley 1991), direct shielding from $\mathrm{KMnO}_{4}$ seems a tenuous explanation. An alternative hypothesis is that TBP alters the conformation of DNA, making it less reactive with $\mathrm{KMnO}_{4}$. Yeast and human TBP have been found to bend DNA, and this bending may result in a lower reactivity with $\mathrm{KMnO}_{4}$ (Horikoshi et al. 1992).

While the TATA protection on the two heat shock genes analyzed in this study was found to be quite strong, two other genes, $\beta-1$ tubulin and histone $H 2 B$, displayed less protection. The differing degrees of TATA protection possibly reflect different modes of interaction between TBP and these genes. One could envision, for example, a more transient interaction of TBP with the $\beta-1$ tubulin and histone $H 2 B$ genes.

\section{Perspectives on polymerase pausing}

What could be the possible advantage of continued pausing on these genes after induction? Pausing of the E. coli RNA polymerase at position +16 on the $\mathrm{pR}^{\prime}$ promoter of phage $\lambda$ allows the modification of polymerase by the phage-encoded Q protein (Roberts 1988). The Q-modified polymerase can then leave the +16 pause site in a form that can read through subsequent pause and termination sites. A similar situation may be occurring on the Drosophila genes where paused polymerase is found. The pausing of RNA polymerase could allow its modification to a form that is more elongationally competent. If this is the case, a slow step early in elongation might increase the overall efficiency with which these genes are transcribed.

Because RNA polymerase II pausing has been found to occur on a large fraction of Drosophila genes examined, the question arises whether promoter-proximal pausing occurs in other organisms. Using transcriptional run-on and $\mathrm{KMnO}_{4}$ sensitivity analyses, Krumm et al. have recently located what appears to be a paused polymerase on the human c-myc gene near +30 (Krumm et al., this volume). We suspect that additional examples of promoter-proximal polymerase pausing will be uncovered.

The activation of the heat shock genes in Drosophila entails the binding of heat shock factor (HSF) to heat shock elements (HSEs) present in the promoter region (Pelham 1982; Pelham and Bienz 1982; Parker and Topol 1984; Wu et al. 1987; Xiao and Lis 1988). Determining precisely which step in the transcriptional pathway is accelerated upon induction therefore has relevance to the activity of HSF. For example, HSF could be stimulating paused polymerase release or polymerase loading. Establishing the mode of action of HSF may also have 
more general implications. The $h s p 70$ proximal promoter (from the TATA box) is compatible with upstream elements and enhancers of other genes. The fat body enhancer element of the Drosophila YP1 gene is effective on the $h s p 70$ proximal promoter (Garabedian et al. 1986), as are the elements of the Drosophila Sgs-3 gene (Martin et al. 1989). Likewise, a model transcriptional inducer from yeast, GAL4, when expressed in Drosophila, will induce an $h s p 70$-derived promoter that has nearby DNA regulatory sequences that bind GAL4 (Fischer et al. 1988). A paused polymerase may be the substrate on which these and other transcriptional activating proteins exert their effect.

\section{Materials and methods}

\section{Cell culture and DNA preparation}

Drosophila Kc cells were grown in D-22 insect cell medium (Sigma) to a density of $\sim 1 \times 10^{7}$ cells $/ \mathrm{ml}$. One-third of these cells was heat-shocked at $36.5^{\circ} \mathrm{C}$ for $20 \mathrm{~min}$. All subsequent handling of cells was done at $0-4^{\circ} \mathrm{C}$. Aliquots of $5 \times 10^{8}$ heatshocked and control cells were pelleted in a clinical centrifuge and resuspended in $465 \mu \mathrm{l}$ of buffer A [ $15 \mathrm{~mm}$ Tris- $\mathrm{HCl}(\mathrm{pH} 7.5)$, $60 \mathrm{~mm} \mathrm{KCl}, 15 \mathrm{~mm} \mathrm{NaCl}, 5 \mathrm{~mm} \mathrm{MgCl}_{2}, 0.5 \mathrm{~mm}$ EGTA, $300 \mathrm{~mm}$ sucrose, $0.5 \mathrm{~mm}$ DTT, $0.1 \mathrm{~mm}$ PMSF]. Cells were either treated with $25 \mathrm{mM} \mathrm{KMnO}_{4}$ through the addition of $36 \mu \mathrm{l}$ of $0.35 \mathrm{M}$ $\mathrm{KMnO}_{4}$ or they were mock treated with $36 \mu$ l of $\mathrm{H}_{2} \mathrm{O}$ (for use as the naked DNA control). After a 30-sec incubation on ice, reactions were stopped through the addition of $500 \mu \mathrm{l}$ of stop solution (50 mM EDTA, $1 \%$ SDS, $0.4 \mathrm{M} \beta$-mercaptoethanol). DNA was isolated by proteinase $\mathrm{K}$ treatment, and phenol-chloroform and chloroform extractions, RNase A treatment, phenol-chloroform and chloroform extractions, and ethanol precipitation [using $0.3 \mathrm{M}$ (Na)acetate]. DNA pellets were washed with $70 \%$ ethanol and dried under vacuum. DNA from mock-treated cells was resuspended in $465 \mu \mathrm{l}$ of buffer $\mathrm{A}$, treated at $0^{\circ} \mathrm{C}$ with $25 \mathrm{mM} \mathrm{KMnO}_{4}$ for $30 \mathrm{sec}$ (stopping the reaction as above), and ethanol precipitated. DNA pellets were then resuspended in 200 $\mu \mathrm{l}$ of $\mathrm{H}_{2} \mathrm{O}$, and the DNA was quantified by reading the absorbance at $260 \mathrm{~nm}$. Although probings have been performed on numerous DNA preparations, all of the genomic probings in this paper that employ the LMPCR methodology were performed on the same DNA preparation. Two to four micrograms of this DNA preparation was cut with the appropriate restriction enzyme (see below), chloroform extracted, ethanol precipitated, dried under vacuum, and resuspended in $90 \mu \mathrm{l}$ of $\mathrm{H}_{2} \mathrm{O}$. Ten microliters of $10 \mathrm{~m}$ piperidine was added to each sample (in screwcap Eppendorf tubes) and heated to $90^{\circ} \mathrm{C}$ in a water-filled heat block for $30 \mathrm{~min}$. After cooling on ice, samples were ethanol precipitated, washed with $70 \%$ ethanol, resuspended in $200 \mu \mathrm{l}$ of $\mathrm{H}_{2} \mathrm{O}$, and dried overnight in a Speed-Vac (Savant). DNA was resuspended in $\mathrm{H}_{2} \mathrm{O}$ at $1 \mu \mathrm{g} / 9 \mu \mathrm{l}$ for amplification by LMPCR.

The $G$ sequence ladders were prepared by treating either cloned $(0.3 \mu \mathrm{g})$ or genomic $(1-4 \mu \mathrm{g})$ DNA (cut with the appropriate restriction enzyme; see below) with $0.5 \%$ dimethylsulfate (DMS) as described in Sambrook et al. (1989). DNA was ethanol precipitated and treated with piperidine (as above), with the final DNA pellet being resuspended at $0.3 \mu \mathrm{g} / 9 \mu \mathrm{l}$ for cloned DNA and at $1 \mu \mathrm{g} / 9 \mu \mathrm{l}$ for genomic DNA for analysis by LMPCR.

\section{Oligonucleotide primers and amplification strategy}

Two gene-specific primers were used for DNA amplification and labeling. The first primer (primer 1) was used for both the Sequenase extension reaction and the initial Taq polymerase amplification, and the second primer (primer 2) was radioactively end-labeled with ${ }^{32} \mathrm{P}$ and used in the Taq polymeraselabeling reaction. All primers were obtained from the Cornell University Oligonucleotide Synthesis Facility and were gel purified before use. Labeling of primer 2 was performed using T4 polynucleotide kinase (Bethesda Research Labs) under conditions described in Sambrook et al. (1989).

Amplification of the $h s p 70$ 87A genes was performed using the following primers: coding strand, primer 1, CACTTTAACTTGCACTTTATTGCAC $(+108$ to +84$)$, and primer 2 , TTGCAGATTGTTTAGCTTGTTCGCTGCGC $(+89$ to +60$)$; transcribed strand, primer 1, GAATATCTTGTCAAAGTTCCATAGGC $(-392$ to -367$)$, and primer 2, GGCCTTTCTGGCGGACAACATCCGC $(-369$ to -345$)$. Amplification of the $h s p 7087 \mathrm{~A}$ genes, and not the $h s p 7087 \mathrm{C}$ genes, was accomplished for the coding strand by cutting the genomic DNA with PstI, which cuts the $87 \mathrm{C}$ genes at +89 . Selective amplification of the $h s p 7087 \mathrm{~A}$ transcribed strand was accomplished using primers for a region of the $h s p 70$ gene where the $87 \mathrm{~A}$ copies have diverged significantly from the $87 \mathrm{C}$ copies $(-345$ to -392$)$ (Ish-Horowicz and Pinchin 1980; Torok and Karch 1980). The hsp26 gene was amplified using the following primers: coding strand, primer 1, GTAGATAGCGACATTTTTACGTTTCC $(+196$ to +171$)$, and primer 2, CGTTTCCTTTAGGTTATGTTCCTTTTGCGAGATTG $(+177$ to +143$)$; transcribed strand, primer 1 , CTCTCTCACTCATACAGGCGCACTA $\mid-327$ to -303), and primer 2, GCACTAGCTCTGCTTTTGCGCGTACGACAA ( -308 to -278 ) (Ingolia and Craig 1982). The $\beta-1$ tubulin gene was amplified using primer 1 , CTTAATGTTATGTCAGGCAAGTGGGATG $(-124$ to -97$)$, and primer 2, GGGATGTTTTAGCACACTAAAACGGGATTTGCG $1-102$ to $-70)$ (Bialojan et al. 1984). The histone H1 gene was amplified using coding strand, primer 1, GGAAGCGTCCACCATTTGCTGAGTT $(+208$ to +184$)$, and primer 2, GAGTTGGCGGATGTGACGGCGTCGCAG (+188 to +162$)$ [|Goldberg 1979); with the start site determined by primer extension (G. Giardina and J. Lis, unpubl.)]. The histone H2B gene was amplified using transcribed strand, primer 1, TTTGGCTTTGCCTGCGCATTCAGTT $(-99$ to -74$)$, and primer 2, CAGTTAGGGGTGGGTGACTTAGACC $(-79$ to -55$)$ (Goldberg 1979). The linker used in the ligation reactions was the same as that described in Mueller and Wold (1989). The calculated melting temperature $\left(T_{\mathrm{m}}\right)$ was used in all annealing reactions: $T_{\mathrm{m}}=81.5+16.6(\log \mathrm{M})+0.41(\% \mathrm{GC})-600 / n$, where $\mathrm{M}$ is molarity of salt and $n$ is nucleotide length (Sambrook et al. 1989).

\section{$L M P C R$}

LMPCR was performed as described previously, with some modifications (Mueller and Wold 1989; Pfeifer et al. 1989). All buffers were prechilled to $0^{\circ} \mathrm{C}$ before use. To $1 \mu \mathrm{g}$ of DNA in 9 $\mu \mathrm{l}$ of $\mathrm{H}_{2} \mathrm{O}, 3 \mu \mathrm{l}$ of primer $1(0.3$ pmole $)$ and $3 \mu \mathrm{l}$ of $5 \times \mathrm{Mg}$-free Sequenase buffer were added $[200 \mathrm{mM}$ Tris- $\mathrm{HCl}(\mathrm{pH} 7.7), 250$ $\mathrm{mm} \mathrm{NaCl}$. Samples were heated to $95^{\circ} \mathrm{C}$ for $2 \mathrm{~min}$ and transferred immediately to the annealing temperature /the calculated $\left.T_{\mathrm{m}}\right)$. After annealing for $30 \mathrm{~min}$, samples were placed on ice and $7.5 \mu \mathrm{l} \mathrm{Mg} / \mathrm{DTT} / \mathrm{dNTP}$ (20 mM $\mathrm{MgCl}_{2}, 20 \mathrm{~mm}$ DTT, $0.2 \mathrm{~mm}$ each dNTP) and $1.5 \mu l(1: 4$ TE diluted) Sequenase (U.S. Biochemical) were added. Samples were incubated at $47^{\circ} \mathrm{C}$ for 5 min and then at $60^{\circ} \mathrm{C}$ for $5 \mathrm{~min}$, after which $6 \mu \mathrm{l}$ of $310 \mathrm{~mm}$ Tris- $\mathrm{HCl}(\mathrm{pH} 7.7)$ was added, followed by a $10-\mathrm{min}$ incubation at $65^{\circ} \mathrm{C}$. Twenty microliters of dilution solution $\left(17.5 \mathrm{mM} \mathrm{MgCl}_{2}\right.$, $42.3 \mathrm{~mm}$ DTT, $12.5 \mu \mathrm{g} / \mathrm{ml}$ of BSA) and $25 \mu \mathrm{l}$ of ligation mixture [10 $\mathrm{mM} \mathrm{MgCl}_{2}, 20 \mathrm{~mm}$ DTT, $3 \mathrm{~mm} \mathrm{ATP}, 50 \mu \mathrm{g} / \mathrm{ml}$ of BSA, 50 
mM Tris- $\mathrm{HCl}$ (pH 7.7), 100 pmoles of annealed linker, 3 units of T4 DNA ligase [U.S. Biochemical)] were added. After an overnight incubation at $17^{\circ} \mathrm{C}$, DNA was ethanol precipitated [using $0.3 \mathrm{M}$ (Na)acetate and $10 \mu \mathrm{g}$ of tRNA carrier], and the pellet was washed with $70 \%$ ethanol and dried under vacuum. Pellets were resuspended in $100 \mu \mathrm{l}$ of ice-cold Taq reaction mixture $[40 \mathrm{~mm}$ $\mathrm{NaCl}, 10 \mathrm{~mm}$ Tris- $\mathrm{HCl}(\mathrm{pH} 8.9$ at room temperature), $5 \mathrm{~mm}$ $\mathrm{MgCl}_{2}, 0.01 \%$ gelatin (wt/vol), $0.2 \mathrm{~mm}$ each of dNTP, 10 pmoles each of primer 1 and the linker primer, 3 units of AmpliTaq DNA polymerase (Perkin-Elmer)], upon which $90 \mu \mathrm{l}$ of mineral oil was layered. Eighteen temperature cycles /using an Ericomp thermal cycler were performed as follows: $1 \mathrm{~min}$ at $94^{\circ} \mathrm{C}\{2 \mathrm{~min}$ for the first cycle); $2 \mathrm{~min}$ at the $T_{\mathrm{m}}$ of primer $1 ; 3 \mathrm{~min}$ at $76^{\circ} \mathrm{C}$. After the 18 rounds of amplification were complete, $10 \mu \mathrm{l}$ of ice-cold labeling mixture $[40 \mathrm{~mm} \mathrm{NaCl}, 10 \mathrm{~mm}$ Tris- $\mathrm{HCl} / \mathrm{pH} 8.9$ at room temperature), $5 \mathrm{~mm} \mathrm{MgCl}, 0.01 \%$ gelatin (wt/vol), 2 mM each of dNTP; about 1 pmole of ${ }^{32} \mathrm{P}$ end-labeled primer 2,1 unit of Amplitaq DNA polymerase] was added, and three or four cycles were performed as follows: $1 \mathrm{~min} 94^{\circ} \mathrm{C} ; 2 \mathrm{~min}$ at the $T_{\mathrm{m}}$ of primer $2 ; 3 \mathrm{~min}$ at $76^{\circ} \mathrm{C}$. After labeling cycles were completed, samples were adjusted to $5 \mathrm{mM}$ EDTA and $0.3 \mathrm{M}(\mathrm{Na}) \mathrm{ac}$ etate, chloroform extracted, ethanol precipitated, and dried under vacuum. Samples were resuspended in formamide loading buffer $[90 \%$ formamide, $0.1 \%$ xylene cyanol, $0.1 \%$ bromophenol blue, $1 \times$ TBE $194 \mathrm{~mm}$ Tris, $65 \mathrm{~mm}$ boric acid, $1.65 \mathrm{~mm}$ EDTA)] and run on a $5 \%$ polyacrylamide $(30: 1$, acrylamide/ bisacrylamide) $/ 7 \mathrm{~m}$ urea, $1 \times$ TBE sequencing gel. Radioactivity on these gels was detected by autoradiography.

\section{Direct primer extension to $\mathrm{KMnO}_{4}$ modification sites}

For experiments performed with isolated nuclei, $\mathrm{KMnO}_{4}$ modification sites were detected by direct primer extension [as described in Becker et al. (1989), with some modifications]. In these experiments, Drosophila SL2 nuclei were isolated using the protocol described in Rougvie and Lis (1988) and incubated under transcriptional run-on conditions either in the presence or absence of $0.6 \%$ sarkosyl (Rougvie and Lis 1988). Nuclei were then treated with $25 \mathrm{~mm} \mathrm{KMnO}_{4}$ at $0^{\circ} \mathrm{C}$ for $15 \mathrm{sec}$, and the reactions were stopped using stop solution. DNA, purified as described above, was digested overnight with EcoRI, phenolchloroform extracted, and spun through a G50-80 (Sigma) column. Ten microgrms of DNA $(55 \mu \mathrm{l})$ was centrifuged in an Eppendorf centrifuge for $10 \mathrm{~min}$ at $12,000 \mathrm{~g}$, and $50 \mu \mathrm{l}$ of the supernatant was transferred to a new tube. Ten microliters of Taq hybridization buffer $\left[100 \mathrm{~mm} \mathrm{MgCl}_{2}, 100 \mathrm{mM}\right.$ tricine $/ \mathrm{pH}$ 8.3 at room temperaturel, $500 \mathrm{mM} \mathrm{KCl}, 10 \mu \mathrm{l}$ of $1 \mathrm{mg} / \mathrm{ml}$ of gelatin, and $5 \mu \mathrm{l}$ of highly radioactive primer $\sim \sim 5000$ decays per sec by Geiger counter, prepared as described below) was added to each sample, and the volume was adjusted to $100 \mu \mathrm{l}$ with $\mathrm{H}_{2} \mathrm{O}$. After boiling for $8 \mathrm{~min}$, samples were transferred to $65^{\circ} \mathrm{C}$ and incubated at this temperature for $3 \mathrm{~min}$. Then $13.8 \mu \mathrm{l}$ of Taq extension buffer $16.8 \mathrm{mM}$ each of dNTP, $100 \mu \mathrm{g} / \mathrm{ml}$ of gelatin, 4 units of Taq polymerase) was added, and samples were incubated at $65^{\circ} \mathrm{C}$ for $45 \mathrm{~min}$. Reactions were stopped by adding $4 \mu \mathrm{l}$ of $0.5 \mathrm{M}$ EDTA and $45 \mu \mathrm{l}$ of TE (pH 8.0) and extracted twice with phenol-chloroform. DNA was precipitated [using $2.5 \mathrm{M}$ $\left(\mathrm{NH}_{4}\right)$ acetate), pellets were washed with $70 \%$ ethanol, dried under vacuum, resuspended in $6 \mu \mathrm{l}$ of formamide loading buffer, and run on a $7 \%$ polyacrylamide $/ 7 \mathrm{M}$ urea sequencing gel as described above. Gel radioactivity was detected by autoradiography.

Highly radioactive primer was prepared by taking 1 pmole of NruI-cut hsp 70 plasmid, or SspI-cut hsp26 plasmid at $50 \mathrm{~mm}$ tricine (pH 7.6), $10 \mathrm{mM} \mathrm{MgCl}_{2}, 0.1 \mathrm{mg} / \mathrm{ml}$ of gelatin, 10 pmoles of unlabeled oligonucleotide [GCTCTCTCACTCTGTC (-124 to $-108 \mid$ for $h s p 70$; and CAGAGTAGATAGCGACATT $(+200$ to +183 ) for $h s p 26]$, and $10 \mu \mathrm{g}$ of $E$. coli single-stranded binding protein (in a $30-\mu \mathrm{l}$ volume) and heating at $90^{\circ} \mathrm{C}$ for $4 \mathrm{~min}$. Samples were then transferred to $37^{\circ} \mathrm{C}$ for $5 \mathrm{~min}$, after which $70 \mu \mathrm{l}$ of a solution containing $0.7 \mathrm{mM} \beta$-mercaptoethanol, $10 \mathrm{mM}$ $\mathrm{MgCl}_{2}, 50 \mathrm{mM}$ tricine (pH 8.0), 50 pmoles each of dNTP [with two being $\left[\alpha^{32} \mathrm{P}\right] \mathrm{dNTP}$ at $3000 \mathrm{Ci} / \mathrm{mmole}$ (Amersham)] and 1.5 units of Klenow enzyme (Bethesda Research Labs) was added. After $30 \mathrm{~min}$ at $37^{\circ} \mathrm{C}$, the reaction was stopped through the addition of $5 \mu \mathrm{l}$ of $0.2 \mathrm{M}$ EDTA, $10 \mu \mathrm{g}$ of salmon sperm DNA, and $100 \mu \mathrm{l}$ of TE (pH 8.0) and chloroform extracted. DNA was ethanol precipitated [using $2.5 \mathrm{M}\left(\mathrm{NH}_{4}\right)$ acetate], washed with absolute ethanol, dried, and purified on a $7 \%$ polyacrylamide $/ 7$ $\mathrm{M}$ urea gel. The gel-eluted primer was ethanol precipitated (with $15 \mu \mathrm{g}$ of tRNA) and dissolved in $20 \mathrm{~mm}$ DTT, $10 \mathrm{~mm}$ tricine $(\mathrm{pH}$ 8.3), and $1 \mathrm{mM}$ EDTA.

\section{TFIID-binding reactions}

Singularly end-labeled $h s p 70$ DNA (from -225 to +108 ) was prepared by performing PCR reactions in which the primer for either the coding or transcribed strand was labeled with ${ }^{32} \mathrm{P}$ by T4 polynucleotide kinase (PCR reactions performed under the conditions used for LMPCR using 20 ng of cloned template). The primers used were CACTTTAACTTGCACTTTATTGCAC $(+108$ to +84$)$ and GGTTGTTGCGCGAGGCATTTGTTTGCC $(-225$ to -199$)$. Approximately 32 fmoles of DNA was incubated in $50 \mu \mathrm{l}$ of buffer $A$ at room temperature for 30 min either with or without $40 \mathrm{ng}$ (two footprinting units, as described by Promega) of the TBP component of human TFIID (Promega). Reactions were treated with $3.5 \mu \mathrm{l}$ of $0.35 \mathrm{M} \mathrm{KMnO}_{4}$ for $30 \mathrm{sec}$, and reactions were stopped with $50 \mu \mathrm{l}$ of stop solution. DNA was ethanol precipitated and treated with piperidine as described above. After piperidine treatment, DNA was ethanol precipitated, resuspended in $200 \mu \mathrm{H}_{2} \mathrm{O}$, and dried overnight in a Speed-Vac. After resuspension in formamide gel loading buffer, DNA was run on a $5 \%$ polyacrylamide $/ 7 \mathrm{~m}$ urea sequencing gel as described above.

\section{Acknowledgments}

We thank J. Ingraffea for growing the Kc cells used in this study and Dr. J. Roberts, Dr. A. Rougvie, M. Fernandes, T. O'Brien, and $\mathrm{E}$. Rasmussen for critical comments on the manuscript. This work was supported by National Institutes of Health (NIH) grant GM25232. C.G. was supported by a NIH postdoctoral fellowship.

The publication costs of this article were defrayed in part by payment of page charges. This article must therefore be hereby marked "advertisement" in accordance with 18 USC section 1734 solely to indicate this fact.

\section{References}

Allison, L.A., M. Moyle, M. Shales, and C.J. Ingles. 1985. Extensive homology among the largest subunits of eukaryotic and prokaryotic RNA polymerases. Cell 42: 599-610.

Becker, M.M., Z. Wang, G. Grossmann, and K.A. Becherer. 1989. Genomic footprinting in mammalian cells with ultraviolet light. Proc. Natl. Acad. Sci. 86: 5315-5319.

Bentley, D.L. and M. Groudine. 1986. A block to elongation is largely responsible for decreased transcription of c-myc in differentiated HL60 cells. Nature 321: 702-706.

Bialojan, S., D. Falkenburg, and R. Renkawitz-Pohl. 1984. Characterization and developmental expression of $\beta-1$ tubulin 
genes in Drosophila melanogaster. EMBO I. 3: 2543-2548.

Borowiec, J.A., L. Zhang, S. Sasse-Dwight, and J.D. Gralla. 1987. DNA supercoiling promotes formation of a bent repression loop in lac DNA. J. Mol. Biol. 196: 101-111.

Buratowski, S., S. Hahn, L. Guarente, and P.A. Sharp. 1989. Five intermediate complexes in transcription initiation by RNA polymerase II. Cell 56: 549-561.

Chinsky, J.M., M.-C. Maa, V. Ramamurthy, and R.E. Kellems. 1989. Adenosine deaminase gene expression: Tissue-dependent regulation of transcriptional elongation. $J$. Biol. Chem. 264: 14561-14565.

Darst, S.A., A.M. Edwards, E.W. Kubalek, and R.D. Kornberg. 1991. Three-dimensional structure of yeast RNA polymerase II at $16 \AA$ resolution. Cell 66: 121-128.

Fischer, J.A., E. Giniger, T. Maniatis, and M. Ptashne. 1988. GAL4 activates transcription in Drosophila. Nature 332: 853-856.

Garabedian, M.J., B.M. Shepherd, and P.C. Wensink. 1986. A tissue-specific transcription enhancer from the Drosophila yolk protein 1 gene. Cell 45: 859-867.

Gilmour, D.S. and J.T. Lis. 1985. In vivo interactions of RNA polymerase II with genes of Drosophila melanogaster. Mol. Cell. Biol. 5: 2009-2018.

- 1986 . RNA polymerase II interacts with the promoter region of the noninduced $h s p 70$ gene in Drosophila melanogaster cells. Mol. Cell. Biol. 6: 3984-3989.

Goldberg, M. 1979. "Sequence analysis of Drosophila histone genes." Ph.D. thesis, Stanford University, Palo Alto, CA.

Greenblatt, J. 1991. Roles of TFIID in transcriptional initiation by RNA polymerase II. Cell 66: 1067-1070.

Hawley, D.K. and R.G. Roeder. 1985. Separation and partial characterization of three functional steps in transcription initiation by human RNA polymerase II. $/$. Biol. Chem. 260: $8163-8172$

Hoey, T., B.D. Dynlacht, M.G. Peterson, B.F. Pugh, and R. Tjian. 1990. Isolation and characterization of the Drosophila gene encoding the TATA box binding protein, TFIID. Cell 61: 1179-1186.

Horikoshi, M., C. Bertuccioli, R. Takada, J. Wang, T. Yamamoto, and R.G. Roeder. 1992. Transcription factor TFIID induces DNA bending upon binding to the TATA element. Proc. Natl. Acad. Sci. 89: 1060-1064.

Ingolia, T.D. and E.A. Craig. 1982. Four small Drosophila heat shock proteins are related to each other and to mammalian alpha-crystallin. Proc. Natl. Acad. Sci. 79: 2360-2364.

Ish-Horowicz, D. and S.M. Pinchin. 1980. Genomic organization of the $87 \mathrm{~A} 7$ and $87 \mathrm{Cl}$ heat-induced loci of Drosophila melanogaster. I. Mol. Biol. 142: 231-245.

Kainz, M. and J. Roberts. 1992. Structure of transcription elongation complexes in vivo. Science 255: 838-841.

Laspia, M.F., A.P. Rice, and M.B. Mathews. 1989. HIV-1 Tat protein increases transcriptional initiation and stabilizes elongation. Cell 59: 283-292.

Lattier, D., J.C. States, J.J. Hutton, and D.A. Winginton. 1989. Cell type specific transcriptional regulation of the human adenosine deaminase gene. Nucleic Acids Res. 17: 10611076.

Lee, D.K., M. Horikoshi, and R.G. Roeder. 1991. Interaction of TFIID in the minor groove of the TATA element. Cell 67: 1241-1250.

Lee, H., K.W. Kraus, M.F. Wolfner, and J.T. Lis. 1992. DNA sequence requirements for generating paused polymerase at the start of $h s p 70$. Genes \& Dev. 6: 284-295.

Marciniak, R.A., B.J. Calnan, A.D. Frankel, and P.A. Sharp. 1990. HIV-1 Tat protein trans-activates transcription in vitro. Cell 63: 791-802.
Martin, M., A. Giangrande, C. Ruiz, and G. Richards. 1989. Induction and repression of the Drosophila Sgs-3 glue gene are mediated by distinct sequences in the proximal promoter. EMBO I. 8: 561-568.

Mueller, P.R. and B. Wold. 1989. In vivo footprinting of a muscle specific enhancer by ligation mediated PCR. Science 246: $780-786$.

Muhich, M.L., C.T. Iida, M. Horikoshi, R.G. Roeder, and C.S. Parker. 1990. cDNA clone encoding Drosophila transcription factor TFIID. Proc. Natl. Acad. Sci. 87: 9148-9152.

Nepveu, A. and K.B. Marcu. 1986. Intragenic pausing and antisense transcription within the murine c-myc locus. EMBO $\mathrm{f}$. 5: 2859-2865.

Nodwell, I.R. and J. Greenblatt. 1991. The nut site of bacteriophage $\lambda$ is made of RNA and is bound by transcription antitermination factors on the surface of RNA polymerase. Genes \& Dev. 5: 2141-2151.

O'Brien, T. and J.T. Lis. 1991. RNA polymerase II pauses at the $5^{\prime}$ end of the transcriptionally induced Drosophila hsp70 gene. Mol. Cell. Biol. 11: 5285-5290.

Parker, C.S. and J. Topol. 1984. A Drosophila RNA polymerase II transcription factor contains a promoter-region-specific DNA-binding activity. Cell 36: 357-369.

Pelham, H.R.B. 1982. A regulatory upstream promoter element in the Drosophila hsp70 heat-shock gene. Cell 30: 517-528.

Pelham, H.R.B. and M. Bienz. 1982. A synthetic heat-shock promoter element confers heat-inducibility on the herpes simplex virus thymidine kinase gene. EMBO I. 1: 1473-1477.

Pfeifer, G.P., S.D. Steigerwals, P.R. Mueller, B. Wold, and A.D. Riggs. 1989. Genomic sequencing and methylation analysis by ligation mediated PCR. Science 246: 810-813.

Platt, T. 1986. Transcription termination and the regulation of gene expression. Annu. Rev. Biochem. 55: 339-372.

Roberts, J.W. 1988. Phage lambda and the regulation of transcription termination. Cell 52: 5-6.

Rougvie, A.E. 1989. "Identification of a post-initiation rate limiting step in the transcription of several Drosophila genes." Ph.D. thesis, Cornell University, Ithaca, NY.

Rougvie, A.E. and J.T. Lis. 1988. The RNA polymerase II molecule at the $5^{\prime}$ end of the uninduced hsp70 gene of $D$. melanogaster is transcriptionally engaged. Cell 54: 795-804.

- 1990. Post-initiation transcriptional control in Drosophila melanogaster. Mol. Cell. Biol. 10: 6041-6045.

Rubin, C.M. and C.W. Schmid. 1980. Pyrimidine-specific chemical reactions useful for DNA sequencing. Nucleic Acids Res. 8: 4613-4619.

Sambrook, J., E.F. Fritsch, and T. Maniatis. 1989. Molecular cloning: A laboratory manual, 2nd ed. Cold Spring Harbor Laboratory Press, Cold Spring Harbor, New York.

Sasse-Dwight, S. and J.D. Gralla. 1988. Probing the E. coli glnALG upstream activation mechanism in vivo. Proc. Natl. Acad. Sci. 85: 8934-8938.

- 1989. $\mathrm{KMnO}_{4}$ as a probe for lac promoter DNA melting and mechanism in vivo. J. Biol Chem. 264: 8074-8081.

Seelitti, M.A., P.A. Pavsco, and D.A. Steege. 1987. lac repressor blocks in vivo transcription of lac control region DNA. Proc. Natl. Acad. Sci. 84: 3199-3203.

Spencer, C.A. and M. Groudine. 1990. Transcription elongation and eukaryotic gene regulation. Oncogene 5: 777-785.

Starr, D.B. and D.K. Hawley. 1991. TFIID binds in the minor groove of the TATA box. Cell 67: 1231-1240.

Thomas, G.H. and S.C.R. Elgin. 1988. Protein/DNA architecture of the DNase I hypersensitive region of the Drosophila hsp26 promoter. EMBO J. 7: 2191-2201.

Torok, I. and F. Karch. 1980. Nucleotide sequences of heat shock activated genes in Drosophila melanogaster. I. Se- 
quences in the regions of the $5^{\prime}$ and $3^{\prime}$ ends of the $h s p 70$ gene in the hybrid plasmid 56H8. Nucleic Acids Res. 8: $3105-$ 3123.

Van Dyke, M.W., R.G. Roeder, and M. Sawadogo. 1988. Physical analysis of transcription preinitiation complex assembly on a class II gene promoter. Science 241: 1335-1338.

von Hippel, P.H., D.G. Bear, W.D. Morgan, and J.A. McSwiggen. 1984. Protein-nucleic acid interactions in transcription: A molecular analysis. Annu. Rev. Biochem. 53: 389-446.

Wang, W., M. Carey, and J.D. Gralla. 1992. Polymerase II promoter activation: Closed complex formation and ATP driven start site melting. Science 255: 450-453.

Wu, C. 1984. Two protein-binding sites in chromatin implicated in the activation of heat-shock genes. Nature 309: 229-234.

Wu, C., S. Wilson, B. Walker, I. Dawid, T. Paisley, V. Zimarino, and H. Ueda. 1987. Purification and properties of Drosophila heat shock activator protein. Science 238: 1247-1253.

Xiao, H. and J.T. Lis. 1988. Germline transformation used to define key features of heat-shock response elements. Science 239: 1139-1142.

Yanofsky, C. 1987. Operon-specific control by transcription attenuation. Trends Genet. 3: 356-360. 


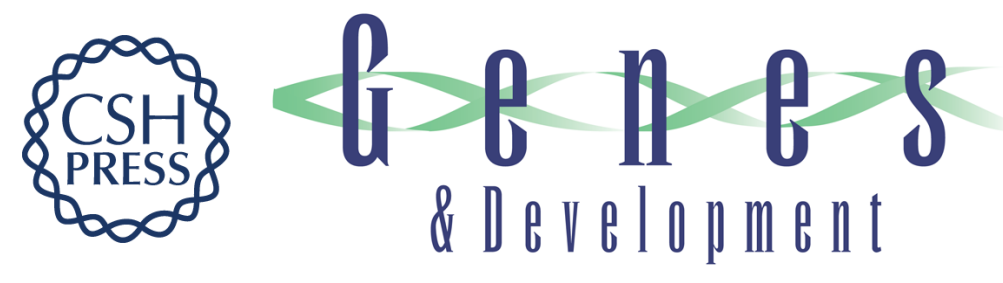

\section{Promoter melting and TFIID complexes on Drosophila genes in vivo.}

C Giardina, M Pérez-Riba and J T Lis

Genes Dev. 1992, 6:

Access the most recent version at doi:10.1101/gad.6.11.2190

References This article cites 53 articles, 22 of which can be accessed free at: http://genesdev.cshlp.org/content/6/11/2190.full.html\#ref-list-1

License

Email Alerting Receive free email alerts when new articles cite this article - sign up in the box at the top Service right corner of the article or click here.

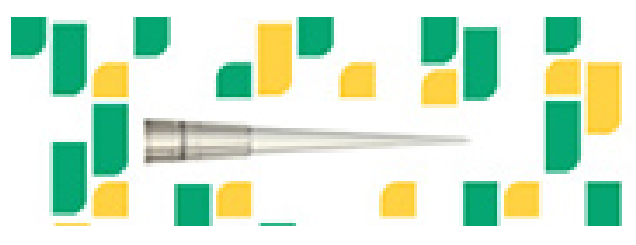

Focused on your science. 